\title{
Research of the Impact of the Heating Rate on Adhesion of Scale Arising in the Process of Heating of the Steel Charge Before the Plastic Reworking
}

\author{
Jarosław Boryca, Cezary Kolmasiak, \\ Tomasz Wyleciał, Dariusz Urbaniak \\ Czestochowa University Of Technology, Poland \\ Jan Kizek \\ Technical University in Košice, Slovak Republic
}

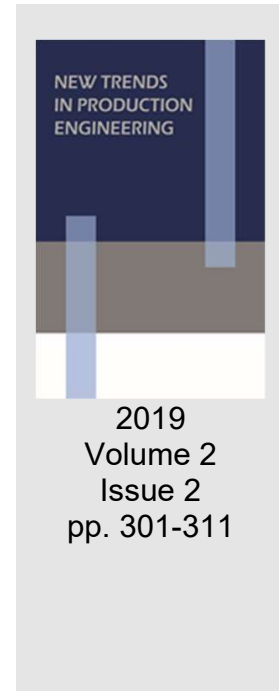

Date of submission to the Editor: 09/2019

Date of acceptance by the Editor: 11/2019

\section{INTRODUCTION}

A plastic processing of hot is preceded by heating the steel charge. The heated charge, contacting with the atmosphere of the working chamber, undergoes oxidation process, resulting in a scale. The presence of scale layer on the surface of the charge is an important issue for both the heating process and subsequent plastic processing. Currently in every area of the economy, including the steel industry, there is a desire to improve the efficiency of production processes, including by reducing the consumption of heat and the substantial reduction. One of the elements contributing to the maintenance of low rates of specific heat consumption and minimal loss of steel scale in the process of heating a charge prior to plastic processing, is the selection of appropriate heating technology. This problem has been widely described in the paper ((Neumann, 1971, Kieloch, 2002, Boryca et al., 2006). Ensuring the quality of semi-finished steel and reduce device failure, both heating and rolling, is conditional on achieving sufficient adhesion of scale during the heating process, and after leaving the furnace by steel charge. The behavior of adhesion of scale to the proper level is important both for the production of sheet metal (Kieloch, 2002, Boryca et al., 2006, Lazič et al., 2008), as well as in the manufacture of steel (Lee \& Kim, 2013, Higginson et al., 2002, Stanković et al., 2012, Bajić et al., 2008, Varga et al., 2007). It can be concluded that the next step in optimizing the heating process should be to development technologies limiting the loss of steel, which simultaneously would guarantee the such adhesion to the steel substrate to mill scale does not fall off in the furnace and was easily removed after leaving it. Previous studies of adhesion of scale related to the effect of temperature and heating time, the furnace atmosphere and the condition of the surface charge (Boryca et al., 2006, Boryca et al., 2015, Tyusenkov \& Cherepashkin, 2014). 


\section{THEORETICAL BASIS}

Scale adhesion to steel substrate is an important element to the selection of heating technology. The value of adhesion is determined by the mechanism of the formation of scale, which is described in the papers (Boryca et al., 2006). One of the parameters of heating technology that determines the consumption of heat and loss of steel by a scale, is the intensity of the increase of the surface temperature of the heated charge (Boryca et al., 2006, Varga et al., 2008, Varga et al., 2009, Wild et al., 2009). Correlation between the amount of the resulting scale of its adhesion can lead to the conclusion that it is necessary to consider the effect of heating rate on the adhesion (Boryca, 2007). The scale occurring in the preheating stage will affect the speed of the process during soaking. The loss of steel in the whole process will therefore be the sum of the losses of the two periods (stages). The loss of steel in the whole heating process is calculated from the equation (Kieloch, 2002):

$$
z^{N}=z_{p}^{N}+z_{w}^{N}
$$

or:

$$
z^{N}=z_{p}^{N}+A_{w} \alpha_{w}^{C} \tau_{w} \exp \left(-\frac{D}{T_{w}}\right)
$$

The loss of steel during preheating in the case of a linear increase of the surface temperature can-calculate from the equation (Kieloch et al., 2006):

$$
z_{p}^{N}=\left[\frac{A \alpha_{p}^{C} \int_{T_{0}}^{T_{p}} \exp \left(-\frac{D}{T}\right) d T}{M}+A \alpha_{w}^{C} \tau_{w} \exp \left(-\frac{D}{T_{w}}\right)\right]^{B}
$$

As soaking proceeds with constant temperature of the surface, the steel loss during this period may be calculated from the equation (Kieloch et al., 2006):

$$
z_{w_{w}}^{N}=A^{\prime} \tau_{w}^{B} \alpha_{w}^{C} \exp \left(-\frac{D}{T_{w}}\right)
$$

or (Kieloch et al., 2006):

$$
z_{w}^{N}=0,405 A \alpha_{w}^{C} \exp \left(-\frac{D}{T_{w}}\right) \frac{s^{2}}{a_{w}} \ln \left(0,516 \frac{M s^{2}}{a_{p}} \frac{1}{\Delta t_{k}}\right)
$$

Thus, with increasing of the heating rate $M$, the steel loss will decrease during the period of preheating and grow during soaking. Finally the equation is obtained (Kieloch, 2002):

$$
Z^{N}=\left[\frac{A \alpha_{p}^{C} \int_{T_{0}}^{T p} \exp \left(-\frac{D}{T}\right) d T}{M}+0,405 A \alpha_{w}^{C} \frac{s^{2}}{a_{w}} \exp \left(-\frac{D}{T_{w}}\right) \ln \left(0,516 \frac{M s^{2}}{a_{p}} \frac{1}{\Delta t_{k}}\right)\right]^{B}
$$

The developed method of calculation of steel loss for two-stage heating allows the calculation for any number of heating stages. Numerical calculation of the steel loss depending on the rate of heating made for the model of pusher furnace (Kieloch, 2002, Golis et al., 1991) have demonstrated that loss of the steel as a function of preheating rate can be described by the following equations (Kieloch et al., 2006):

$$
\begin{aligned}
& z=\frac{341,8}{M}+0,781 \cdot \ln (0,0406 \cdot M) \\
& z=3,051+7,375 \cdot \exp (-0,0162 \cdot M) \\
& z=2,862 \cdot \exp (0,00011 \cdot M)+6,0622 \cdot \exp (-0,0132 \cdot M)
\end{aligned}
$$




$$
z=2,674+\frac{171,876}{M}
$$

The results of studies (Kieloch, 2010) indicate that there is a rational rate of preheating, allowing to achieve a minimum loss of steel scale and maximum reduction of heat consumption. It is anticipated that similar results can be achieved when considering the scale adhesion to the steel substrate.

\section{MEASUREMENT SYSTEM}

The heating process was undertaken in an electric tube furnace (with combustion chamber) equipped with a programmable controller SHIMADENFP93 (Fig. 1).

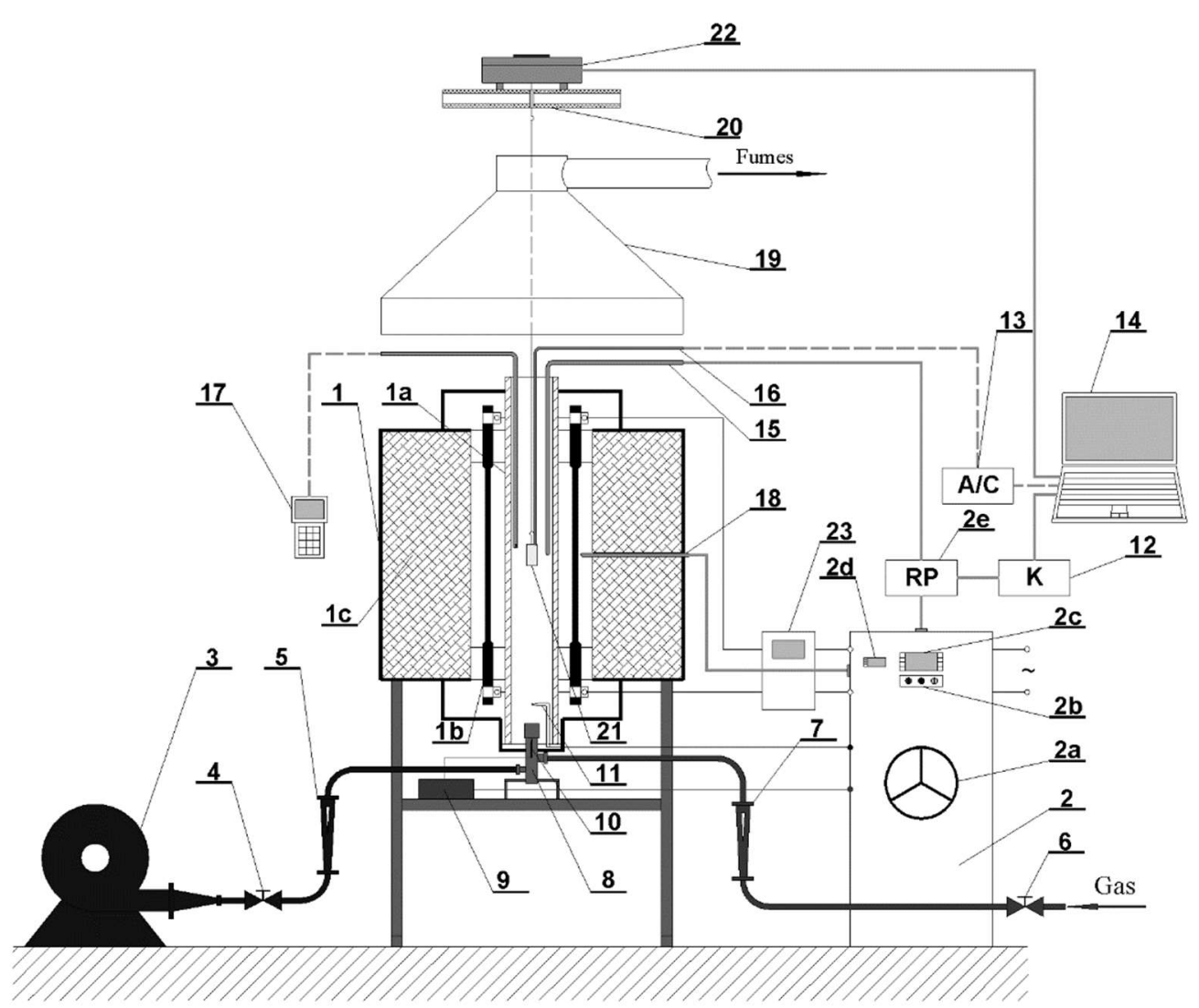

Fig. 1 Test stand scheme:

1. Electric tube furnace, 1a) cylindrical chamber, 1b) resistance heating elements, 1c) thermal insulation, 2. The three-phase power supply cabinet, 2a) steering wheel to adjust the power settings of the furnace, $2 b$ ) desktop with additional features, $2 c$ ) keyboard and display of programmable controller, 2d) keyboard and display of the automatic security delimiter,

2e) programmable controller SHIMADEN - FP93, 3. Radial fan KONWEKTOR - WP-7,6, 4.

Air valve, 5. Rotameter to measure the flow of the combustion air, 6. Gas valve, 7. Rotameter for the measure the flow of natural gas, 8. Gas burner, 9. Power transformer spark igniter, 10. Spark igniter, 11. Thermocouple flame control, 12. Converter YUKO - KO-485d, 13. A/D Card,

14. Notebook with software, 15. Control thermocouple PtRh10 (S), 16. Thermocouple PtRh10-Pt (S) or $\mathrm{NiCr}-\mathrm{Ni}(\mathrm{K})$ to measure the temperature on the surface of the test sample, 17. Portable gas analyzer TESTO 350, 18. Control thermocouple, 19. Exhaust gas, 20. Isolated shelf for balance,

21. Test steel sample, 22. Electronic precision balance, 23. Electronic meter of electric energy

The process was carried out in two stages: preheating and soaking. The launch of the measuring system required previous programming of the heating characteristics using the controller. Determination of the heating characteristics relied on the amount of time steps and the maximum temperature for a given 
step. After running the program the furnace automatically realized the heating process in well-defined steps.

The principle operation of the test stand has been presented in the article (Kieloch, 2002, Pilarczyk, 2006). The scale adhesion apparatus for descaling was designed and built. This is outlined in (Boryca et al., 2006).

\section{METHODS OF ADHESION MEASURING}

In order to achieve the research objectives, measurement methodology of adhesion for both hot and cold load was prepared. Mass method was applied, used for hot samples (Boryca et al., 2006). This method involves weighing samples in successive stages of the research. The adhesion of the scale layers can be expressed by mass scale rest after breaking into her total mass. The value of this adhesion determines the equation:

$$
P_{m}=\frac{m_{2}-m_{3}}{m_{1}-m_{3}} \cdot 100 \%
$$

where:

$\mathrm{m}_{1}$ - mass of the sample after heating, $\mathrm{kg}$,

$\mathrm{m}_{2}$ - mass of the sample after breaking the scale, $\mathrm{kg}$,

$\mathrm{m}_{3}$ - mass of the sample after cleaning, $\mathrm{kg}$,

$P_{m}$ - adhesion of scale for the mass method, \%.

Mass $m_{2}$ and $m_{3}$ are determined by weighing samples using an electronic balance WPS-360/C. To determine the mass $m_{1}$ is the equation:

$$
m_{1}=m_{0}+\frac{z \cdot A}{0,74}
$$

where:

mo - sample mass before heating, $\mathrm{kg}$,

$\mathrm{z}$ - steel loss by scale, $\mathrm{kg} / \mathrm{m}^{2}$,

A - sample surface, $\mathrm{m}^{2}$.

In order to calculate the loss of steel equation was used:

$$
z=\frac{m_{0}-m_{3}}{A}
$$

\section{HEATING CURVES AND THEIR VERIFICATION}

As presented above, carrying out experimental tests requires proper control of the furnace operation. This was done by controlling surface temperature of the sample. The temperature of the furnace chamber rises in the preheating process. The increase of the chamber temperature does not however evenly heat the charge throughout its volume. The charge is characterized by a specific value of thermal conductivity and a specified thickness. Therefore it require heating to a setpoint temperature for a limited period of time in the chamber at a constant temperature (soak period).

The increase of heating rate raises the temperature gradient over the crosssection of the charge. Therefore soaking time will increase with raising heating rate. Soaking times, for the designated heating tests, was found using computer programs to calculate the two-stage charge heating (preheating and soaking).For the designated heating curves the temperature of the sample 
surface and the heating chamber were measured. The results of calculations for an exemplary heating rate $\mathrm{M}=200 \mathrm{~K} / \mathrm{h}$ are shown in Fig. 2.

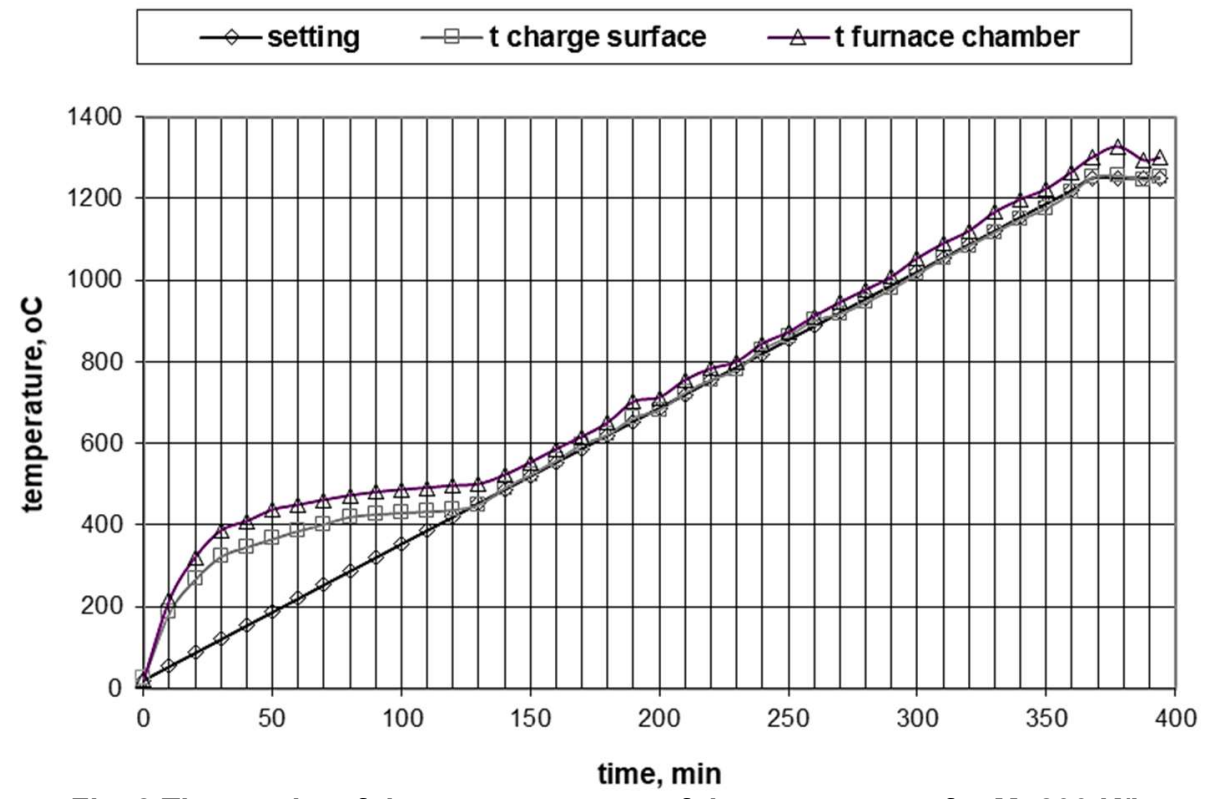

Fig. 2 The results of the measurements of the temperature for $M=200 \mathrm{~K} / \mathrm{h}$

Analyzing Fig. 2, it can be concluded that the heating to a temperature of about $400^{\circ} \mathrm{C}$ is characterized by a non-linear increase in the temperature of the charge surface. Such situation is caused by the influence of thermal energy supplied from a gas burner whose power cannot be adjusted at steady flows of gas and combustion air. Once at the temperature of the sample surface greater than $400^{\circ} \mathrm{C}$, this parameter is characterized by an almost linear nature of the increase. Deviation from the setting is approximately $\pm 15^{\circ} \mathrm{C}$, and the mean value of the deviation of $+2^{\circ} \mathrm{C}$. Surface temperature deviation from the setting to a temperature of $400^{\circ} \mathrm{C}$ does not have a significant impact on the scale adhesion to the substrate steel, because in this area the scale formed with smaller quantities. The adhesion of scale at temperatures below $1000^{\circ} \mathrm{C}$ is at a level not exceeding $5 \%$ (Boryca et al., 2006). The temperature of the operating cell (heating) is maintained at an average level around $40^{\circ} \mathrm{C}$ above the temperature of the sample surface. The average increase in surface temperature of the sample is $33.2 \mathrm{~K} / 10 \mathrm{~min}$, giving a value of $199.2 \mathrm{~K} / \mathrm{h}$ or almost equal to $200 \mathrm{~K} / \mathrm{h}$. Similar dependencies and deviations from the set curve of the heating was obtained for the remaining heating rate. Adopted the setting of the furnace temperature can therefore be considered as correct.

\section{THE RESULTS OF MEASUREMENTS AND CALCULATIONS SCALE ADHE-} SION AND STEEL LOSS BY SCALE

The measurements were performed for samples of steel St4S square section $30 \times 30 \mathrm{~mm}$ and a height of $50 \mathrm{~mm}$. The heating was conducted in an atmosphere of exhaust gas, the excess air ratio combustion 1,2 to the temperature of the charge surface $t=1250^{\circ} \mathrm{C}$. The heating rate $\mathrm{M}=100,200,300,400,500$ and $600 \mathrm{~K} / \mathrm{h}$ were analyzed. First heating measurement was performed only for the 
preheating stage, then for a two-stage heating (preheating and soaking) at the same heating rate. Control the composition of the furnace atmosphere (the excess of the combustion air) made by fixing appropriate setting rotameters of air and gas. As part of preliminary tests measurements of the samples mass were carried out and determined their dimensions. The surface area of the samples were calculated. The results of measurements and calculations are presented in Table 1.

Table 1 The results of measuring the mass and initial dimensions of the sample

\begin{tabular}{|c|c|c|c|c|c|}
\hline $\begin{array}{l}\text { The method } \\
\text { of the heating } \\
\text { carrying out }\end{array}$ & $\begin{array}{c}\text { The } \\
\text { preheating } \\
\text { rate } \mathrm{M}, \mathrm{K} / \mathrm{h}\end{array}$ & $\begin{array}{c}\text { The initial } \\
\text { mass } \\
\text { of the sample } \\
\text { mo, } \mathrm{g}\end{array}$ & $\begin{array}{c}\text { The initial } \\
\text { height } \\
\text { of the sample } \\
\text { h, } \mathrm{mm}\end{array}$ & $\begin{array}{c}\text { The initial size } \\
\text { of the side } \\
\text { of the sample } \\
\text { a, } \mathrm{mm}\end{array}$ & $\begin{array}{c}\text { The area } \\
\text { of the sample } \\
A, \mathrm{~m}^{2}\end{array}$ \\
\hline \multirow{6}{*}{$\begin{array}{l}\text { The stage } \\
\text { of the } \\
\text { preheating }\end{array}$} & 100 & 322,987 & 50,5 & 29,0 & 0,007540 \\
\hline & 200 & 323,276 & 51,0 & 29,0 & 0,007598 \\
\hline & 300 & 322,362 & 49,5 & 29,5 & 0,007582 \\
\hline & 400 & 323,622 & 51,0 & 29,0 & 0,007598 \\
\hline & 500 & 323,892 & 50,0 & 30,0 & 0,007800 \\
\hline & 600 & 321,470 & 51,0 & 28,5 & 0,007439 \\
\hline \multirow{6}{*}{$\begin{array}{l}\text { The process } \\
\text { of two-step }\end{array}$} & 100 & 317,926 & 50,5 & 29,0 & 0,007540 \\
\hline & 200 & 310,792 & 49,5 & 29,0 & 0,007424 \\
\hline & 300 & 321,127 & 50,5 & 29,5 & 0,007700 \\
\hline & 400 & 324,570 & 51,5 & 29,5 & 0,007818 \\
\hline & 500 & 322,622 & 51,0 & 29,5 & 0,007759 \\
\hline & 600 & 320,295 & 51,0 & 29,0 & 0,007598 \\
\hline
\end{tabular}

The next stage of research included measuring the masses of the samples after descaling and total cleaning their surface. The measurement results are compiled in Table 2.

Table 2 The results of measuring samples mass after descaling and cleaning

\begin{tabular}{|l|c|c|c|}
\hline \multirow{2}{*}{$\begin{array}{c}\text { The method of the } \\
\text { heating carrying out }\end{array}$} & $\begin{array}{c}\text { The preheating } \\
\text { Rate } \mathbf{M}, \mathbf{K} / \mathbf{h}\end{array}$ & $\begin{array}{c}\text { The sample mass after } \\
\text { descaling } \mathbf{~ m}_{\mathbf{2}} \mathbf{g}\end{array}$ & $\begin{array}{c}\text { The sample mass after } \\
\text { total cleaning } \mathbf{~ m}_{\mathbf{3}}, \mathbf{g}\end{array}$ \\
\hline \multirow{4}{*}{$\begin{array}{l}\text { The stage } \\
\text { of the preheating }\end{array}$} & 100 & 322,196 & 296,963 \\
\cline { 2 - 4 } & 200 & 321,892 & 299,140 \\
\cline { 2 - 4 } & 300 & 320,549 & 299,865 \\
\cline { 2 - 4 } & 400 & 319,338 & 308,605 \\
\hline \multirow{4}{*}{ The process } & 500 & 317,718 & 309,201 \\
\cline { 2 - 4 } & 600 & 315,915 & 310,768 \\
\cline { 2 - 4 } & 100 & 317,196 & 275,963 \\
\cline { 2 - 4 } & 200 & 309,493 & 278,414 \\
\cline { 2 - 4 } & 300 & 319,391 & 294,165 \\
\cline { 2 - 4 } & 400 & 319,254 & 299,697 \\
\cline { 2 - 4 } & 500 & 318,211 & 295,264 \\
\hline
\end{tabular}

Calculations the steel loss, samples mass after heating and scale adhesion for the analyzed heating rate were made. The results of the calculations are presented in Table 3.

The results of scale adhesion for the heating stage and two-stage heating are shown in Fig. 3.

Graph Fig. 3 shows that with an increase of the heating rate the scale adhesion to a steel substrate for the heating stage is decreasing. 
Table 3 The results of calculations of steel loss,

samples mass after heating and scale adhesion

\begin{tabular}{|c|c|c|c|c|}
\hline $\begin{array}{l}\text { The method } \\
\text { of the heating } \\
\text { carrying out }\end{array}$ & $\begin{array}{l}\text { The preheating } \\
\text { rate } M, K / h\end{array}$ & $\begin{array}{c}\text { The steel loss by } \\
\text { scale } z, \mathrm{~kg} / \mathrm{m}^{2}\end{array}$ & $\begin{array}{l}\text { The sample mass } \\
\text { after heating } m_{1}, g\end{array}$ & $\begin{array}{c}\text { The scale } \\
\text { adhesion } \mathrm{P}, \%\end{array}$ \\
\hline \multirow{6}{*}{$\begin{array}{l}\text { The stage } \\
\text { of the } \\
\text { preheating }\end{array}$} & 100 & 3,451 & 358,155 & 41,24 \\
\hline & 200 & 3,177 & 355,892 & 40,09 \\
\hline & 300 & 2,967 & 352,763 & 39,10 \\
\hline & 400 & 1,976 & 343,915 & 30,40 \\
\hline & 500 & 1,883 & 343,745 & 24,66 \\
\hline & 600 & 1,439 & 335,932 & 20,45 \\
\hline \multirow{6}{*}{$\begin{array}{l}\text { The process } \\
\text { of two-step }\end{array}$} & 100 & 5,565 & 374,633 & 41,79 \\
\hline & 200 & 4,361 & 354,546 & 40,82 \\
\hline & 300 & 3,502 & 357,562 & 39,79 \\
\hline & 400 & 3,182 & 358,182 & 33,44 \\
\hline & 500 & 3,526 & 359,592 & 35,67 \\
\hline & 600 & 4,299 & 364,434 & 39,01 \\
\hline
\end{tabular}

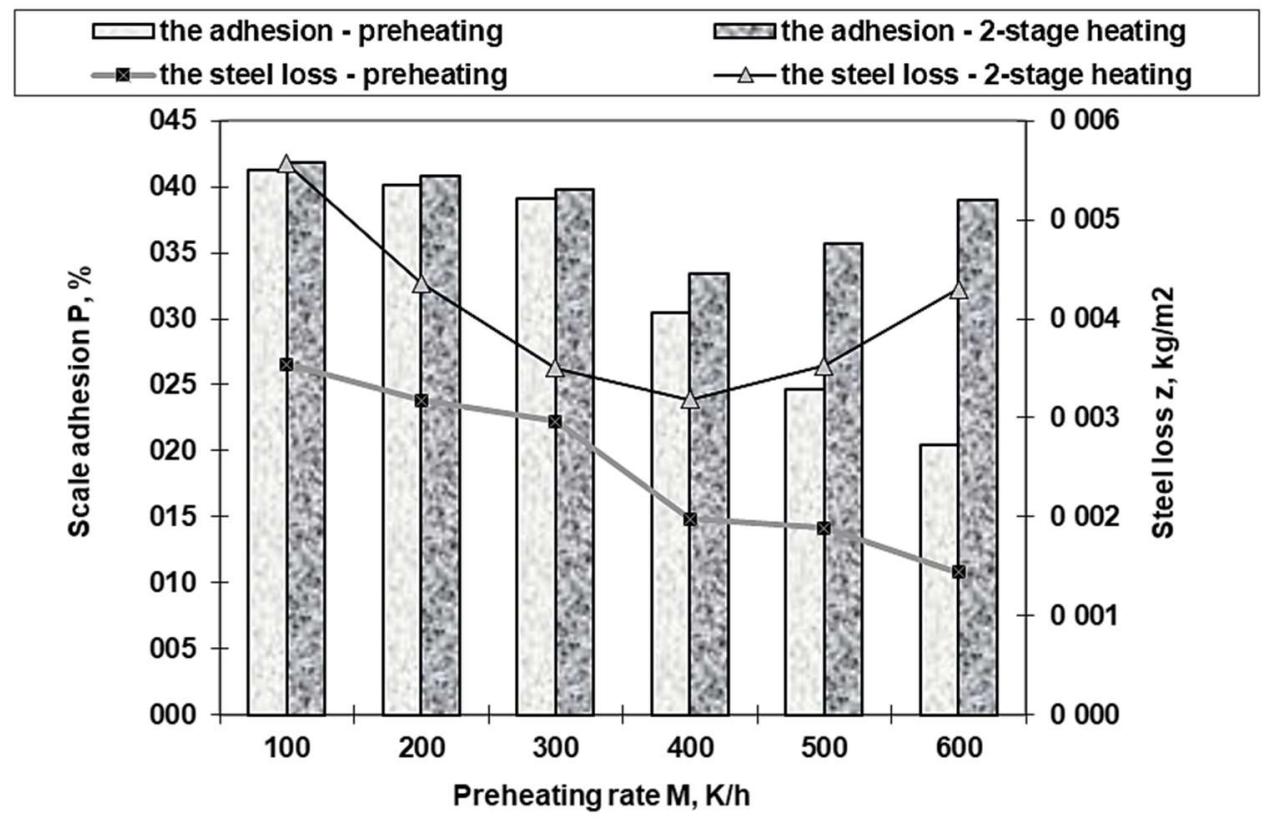

Fig. 3 The results of the scale adhesion and the steel loss for the heating stage and 2-stage heating

The lowest value was obtained for $M=600 \mathrm{~K} / \mathrm{h}$. After taking into account the period of temperature compensation, the lowest value of adhesion obtained for the heating rate $M=400 \mathrm{~K} / \mathrm{h}$. The scale adhesion for individual heating rate reaches a value very similar and the higher, compared with the period of preheating, the higher the heating rate. For speed $M=600 \mathrm{~kg} / \mathrm{h}$ adhesion has almost doubled, while for $M=100 \mathrm{~K} / \mathrm{h}$ the increase is almost imperceptible. Simultaneously it can be seen that for two-stage heating adhesion behaves like a loss of steel. Adhesion values in the individual heating stage are determined by the residence time of the charge in temperatures determining the adhesion (above $1000^{\circ} \mathrm{C}$ ). The regularity for selected heating rate is shown in Fig. 4.

Analyzing Fig. 4 it can be concluded that the value of adhesion depends on the residence time at temperatures above $1000^{\circ} \mathrm{C}$. Such a thesis also is confirmed by the results of research presented at paper (Halusiak et al., 2012). 


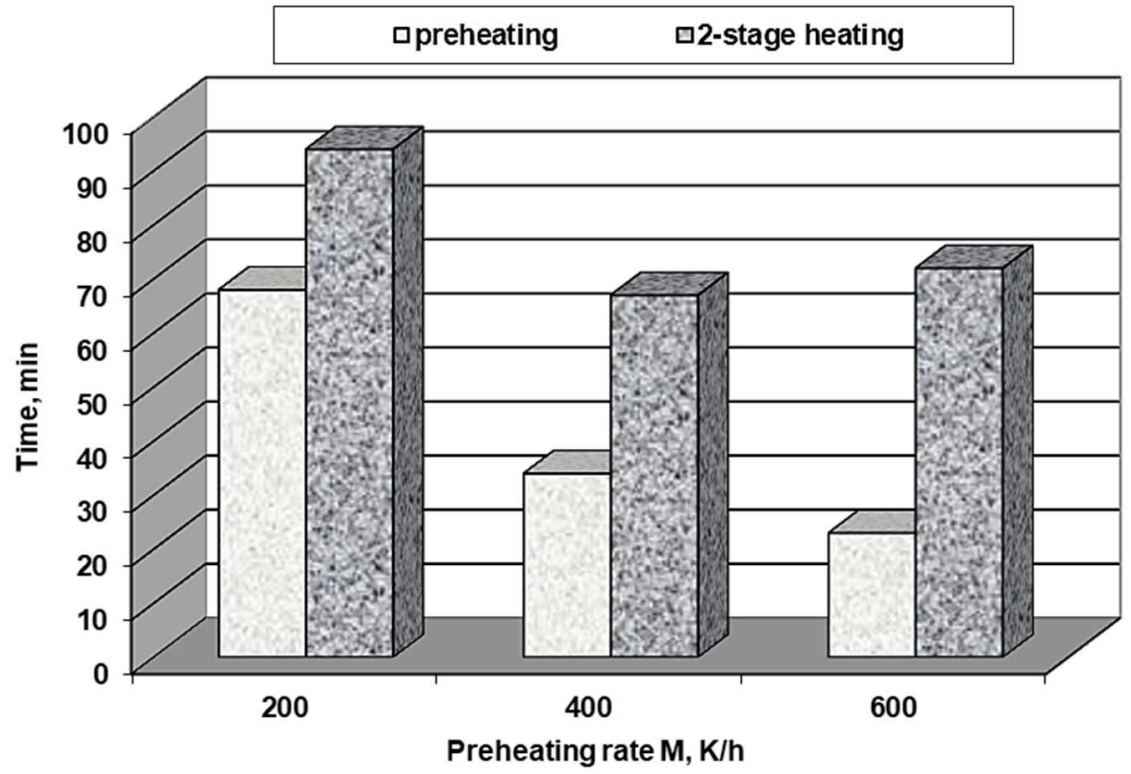

Fig. 4 The residence time of the steel samples at temperatures above $1000^{\circ} \mathrm{C}$ for the preheating stage and two-stage heating

\section{THE INFLUENCE OF THE HEATING RATE ON ADHESION}

Mathematical analysis of the research results were brought to devise depending describing the impact of heating rate on the scale adhesion to a steel substrate for the two-stage heating because preheating stage does not occur in practice without the stage of the temperature leveling. To analyze the effect of heating rate on the adhesion of scale were taken into consideration the following functions:

$$
\begin{aligned}
& P=33,345+0,14322 \cdot M-7,07688 \cdot 10^{-4} \cdot M^{2}+1,08486 \cdot 10^{-6} . \\
& M^{3}-4,60417 \cdot 10^{-10} \cdot M^{4}, \\
& P=\frac{0,28768}{M^{-1,34}} \\
& P=41,269-8,09152 \cdot \exp \left[-0,5 \cdot\left(\frac{M-43,38262}{84,61959}\right)^{2}\right], \\
& P=42,01556-850,83769 \cdot \frac{166,39539}{4 \cdot(M-438,52238)^{2}+(166,39539)^{2}}
\end{aligned}
$$

The calculations of the scale adhesion and statistical errors generated using mathematical functions have been made. The values of error statistics are compiled in Table 4.

Table 4 The results of calculations of steel loss, samples masses after heating and scale adhesion

\begin{tabular}{|c|c|c|c|}
\hline $\begin{array}{c}\text { No } \\
\text { dependencies }\end{array}$ & $\begin{array}{c}\text { The correlation } \\
\text { coefficient }\end{array}$ & $\begin{array}{c}\text { The sum of squared } \\
\text { deviations, } \boldsymbol{\Sigma}^{\mathbf{2}} \text { dev. }\end{array}$ & $\begin{array}{c}\text { The average error } \\
\text { of the approximation, } \boldsymbol{\delta} \text { [\%] }\end{array}$ \\
\hline 14 & 0,935 & 2,312 & 6,519 \\
\hline 15 & 0,999 & 2,116 & 5,515 \\
\hline 16 & 0,977 & 1,555 & 2,336 \\
\hline 17 & 0,960 & 8,054 & 89,735 \\
\hline
\end{tabular}

Taking into account the value of the statistical error, it was found that the best correlation between the adhesion and the heating rate reproduces relation (15). The dependence of the adhesion on the heating rate using the research results and a mathematical function are shown in Fig. 5. 


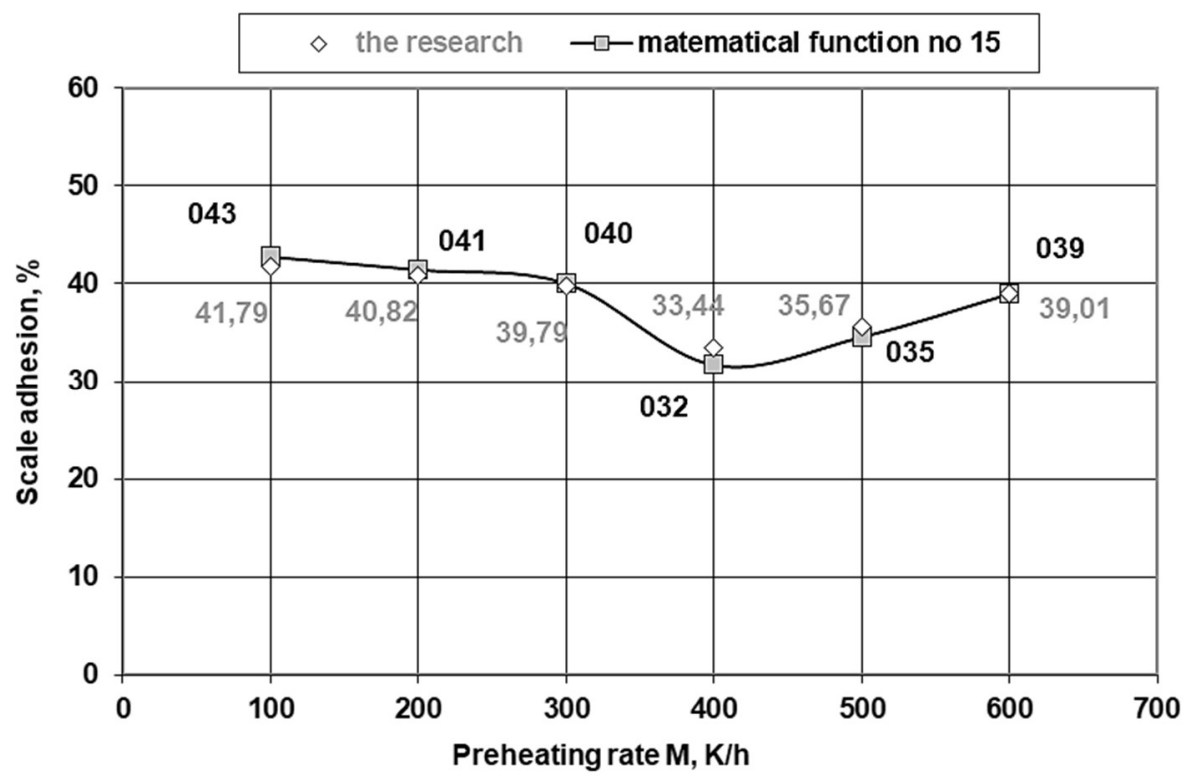

Fig. 5 The influence heating rate on the scale adhesion for the results of research and using the dependence (15)

The calculations indicate statistical error high precision features (14)-(16), but using of the equation (15) is proposed, due to possibility of application issues of scale adhesion to the mathematical considerations.

\section{STATEMENTS AND CONCLUSIONS}

The following conclusions can be specify on the basis of theoretical performed analysis and experimental research laboratory:

a) The heating rate affected on both the steel loss, and the scale adhesion to a steel substrate.

b) For the heating stage the scale adhesion decreases with increasing of the heating rate.

c) The application of the two-stage heating, which is necessary to compensate for the temperature difference at the charge section of the steel, results in an increase in adhesion when compared to the preheating stage.

d) The calculation results may indicate that the rational heating rate will be approximately $\mathrm{M}=400 \mathrm{~K} / \mathrm{h}$.

e) The scale adhesion to steel substrate retains a similar trend as the steel loss by scale.

f) The values of the scale adhesion are determined by residence time at temperatures deciding about adhesion (above $1000^{\circ} \mathrm{C}$ ).

g) The influence of heating rate for 2-stage heating process can be accurately describe mathematical dependencies.

h) It is proposed to use dependence (15) characterizing by small statistical errors, and yet easy to use in further considerations.

\section{REFERENCES}

Neumann F. (1971) Metallurgische Betrachtungen zum Oxydationsverhalten von Stahl bein Erwarmen, Harterei-Tech. Mitt., nr 3, pp. 198-207. 
Kieloch M. (2002) Energooszczędne i mało zgorzelinowe nagrzewanie wsadu stalowego, Prace naukowe Wydziału Inżynierii Procesowej, Materiałowej i Fizyki Stosowanej, Seria Metalurgia $\mathrm{nr} 29$

Boryca J., Kieloch M., Piechowicz $Ł$. (2006) Investigation of the adhesion of scale forming in the process of steel charge heating before plastic working, Archives of Metallurgy and Materials, v.51, nr 3, pp. 451-457.

Lazič L., Varga A., Brovkin V. L., Kizek J. (2008) Impact of the load structural defects on the allowed heating rate in reheating furnaces. Teplotechnika i energetika $v$ metallurgii. -Dnepropetrovsk: Nova ideologija, s. 279-280.

Lee D.E., Kim M.Y. (2013) Optimum residence time for steel productivity and energy saving in a hot rolled reheating furnace, Journal of Mechanical Science and Technology, September, Volume 27, Issue 9, pp 2869-2877

Higginson R. L., Roebuck B., Palmiere E. J. (2002) Texture development in oxide scales on steel substrates, Scripta Materialia, nr 47, s. 337-342.

Stanković I., Perinić M., Jurković Z., Mandić V., Maričić S. (2012) Usage of neural network for the prediction of surface roughness after the roller burnishing, Metalurgija 51, 2, 207-210.

Bajić D., Lela B., Živković D. (2008) Modeling of machined surface roughness and optimization of cutting parameters in face milling, Metalurgija 47, 4, pp. 331-334.

Varga A., Seman J., Hala K., Vilk J. (2007) Making the primary scales by slab reheating. In: Acta Metallurgica Slovaca. v.13, special issue 3, pp. 387-391.

Golis B., Pilarczyk J. W., Błażejewski Z. (1991) Druty stalowe, Politechnika Częstochowska, Prace dydaktyczne, Seria Metalurgia nr 35,

Pilarczyk J. W., (2006) Wybrane zagadnienia ciągnienia drutów ze stali wysokowęglowych, Prace naukowe Wydziału Inżynierii Procesowej, Materiałowej i Fizyki Stosowanej, Seria Monografie nr 115

Kciuk R., Lewandowski S., Golis B., Pilarczyk J. W. (2000) Exploitation features of stream descaling of steel wire rods, Wire Journal, pp. 150

Boryca J., Wyleciał T., Urbaniak D. (2015) The Effect of Condition of the Charge Surface on the Scale Adhesion for Excess Air Combustion, Metalurgija, Vol.54 nr 1, pp. 83-86.

Tyusenkov A.S., Cherepashkin S.E. (2014) Scale inhibitor for boiler water systems, Russian Journal of Applied Chemistry, 87, 9, p.1240-1245.

Varga A., A. Lazič A., Seman J. (2008) Influence of fill powder on scale making by steel reheating, Teplotechnika i energetika $v$ metallurgii. - Dnepropetrovsk: Nova ideologija, p. 283-285.

Varga A., Kizek J., Tatič M., Lazić L., Repášová M. (2009) Scales - the consistent problem during the reheating slabs in push furnacesln: Monuments of Old Metallurgy as Heritage of European Culture : international scientific conference: 911 September 2009, Sielpia. - Częstochowa, pp. 103-110.

Wild D., Meurer T., Kugi A. (2009) Modelling and experimental model validation for a pusher-type reheating furnace, Mathematical and Computer Modelling of Dynamical Systems, vol. 15, no. 3, pp. 209-232.

Boryca J. (2007) The effect of loss of steel and thickness of scale layer on the scale adhesion for constant value excess combustion ratio, Acta Metallurgica Slovaka r. 13, pp. 262-268.

Kieloch M., Boryca J., Piechowicz Ł. (2006) Modelowanie utleniania stali w dwuetapowym procesie nagrzewania, Hutnik- Wiadomości Hutnicze, nr 2, str. 60 64.

Kieloch M. (2010) Racjonalizacja nagrzewania wsadu, Wyd. WIPMiFS Pol. Częstochowskiej, Seria Monografie nr 8

Halusiak B., Kieloch M., Boryca J. (2012) Investigation of the effect of heating time on the scale adhesion, New technologies and achievements", Monografie nr 25, Wyd. Wydziału Inżynierii Procesowej, Materiałowej i Fizyki Stosowanej PCz, s. 30-39. 


\begin{abstract}
.
Before steel materials are subjected to an appropriate heat treatment, they must be preheated. During this process scale is formed, which can be a problem in the proper heat treatment of the steel charge. The preheating process of the steel charge is carried out under specific conditions - parameters. These conditions determine certain properties of scale. One of the most important issues in this context, important from the point of view of the potential removal of scale from the charge surface, is the correlation of the heating process temperature and the adherence of the scale to the steel substrate. The paper presents the results of such research and their discussion. In addition, the methodology for measuring the scale adhesion to steel substrate is presented. Mathematical relations endearing impact of heating rate on the scale adhesion have been developed.
\end{abstract}

Keywords: heating of charge, preheating rate, heating technology, loss of steel, adhesion of scale 